\title{
Wyjście z kryzysu - proces stabilizacji oraz odbudowa państwa afgańskiego
}

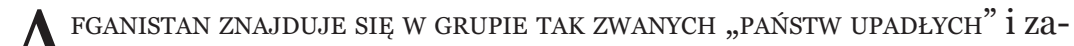
Aliczany jest do grona wspierających zjawisko terroryzmu na świecie $^{1}$. Punktem zwrotnym w historii tego kraju na początku XXI w. stał się atak terrorystyczny na World Trade Center w Nowym Jorku 11 września 2001 r. Po upływie miesiąca od tego wydarzenia rozpoczęto działanie przeciwko terrorystom ${ }^{2}$. Podczas spotkania przedstawicieli Sojuszu Północnoatlantyckiego w dniu 12 września $2001 \mathrm{r}$. po raz pierwszy odwołano się do klauzuli wzajemnego bezpieczeństwa zawartej w artykule 5. Paktu Północnoatlantyckiego. 7 października 2001 r. siły powietrzne USA zaatakowały lotniska talibów. Jednocześnie stanowiło to początek operacji „Trwała Wolność”, zbrojnej kampanii przeciwko terroryzmowi. Do koalicji tej dołączyły również Rosja oraz część państw członkowskich Unii Europejskiej i sojusznicy z NATO ${ }^{3}$. W walce tej wsparcia udzieliły także państwa Azji Środkowej4 ${ }^{4}$ Podjęte kroki doprowadziły do obalenia reżimu talibów ${ }^{5}$. Akcję przeprowadzoną przeciwko Afganistanowi uznano za samoobronę spowodowaną napaścią zbrojną ${ }^{6}$. Warto powtórzyć za Piotrem Jastrzębskim, że konflikt afgański przebiega z dala od rozwiniętych państw świata7 ${ }^{7}$ Należy jednocześnie zauważyć, że operacja Sojuszu
\end{abstract}

${ }_{1}$ Zob. P. Jastrzębski, Wojna $w$ Afganistanie, [w:] Zbrojne konflikty i spory międzynarodowe w progu XXI wieku. Analiza problemów i studia przypadków, red. W. Malendowski, Wrocław 2003, s. 268.

${ }^{2}$ Zob. S. Koziej, Regiony konfliktów i kryzysów: Bałkany, Irak, Afganistan, [w:] Bezpieczeństwo w stosunkach transatlantyckich, red. J. Gryz, Toruń 2008, s. 433.

${ }^{3}$ P. Jastrzębski, Wojna $w$..., op. cit., s. 272-273, 276.

4 R. Kupicki, NATO a terroryzm. Nowy etap transformacji Sojuszu, „Sprawy międzynarodowe" 2001, nr 3, s. 20.

${ }^{5}$ J. Stachura, Bliskowschodnia polityka Baracka Obamy - szanse i wyzwolenia, „Sprawy międzynarodowe” 2009, nr 4, s. 27.

${ }^{6}$ J. Kranz, Użycie sity zbrojnej - nowe fakty i tendencje, „Sprawy Międzynarodowe” 2006, nr 3, s. 79.

${ }^{7}$ Cyt. za: P. Jastrzębski, Wojna w..., op. cit., s. 243. 
wykracza poza obszar traktatowy ${ }^{8}$. Nie bez znaczenia jest jednak fakt, że operacja militarna zwróciła uwagę muzułmanów na świecie, szczególnie grona fundamentalistów islamskich.

DZIAEANIA SPOŁECZNOŚCI MIĘDZYNARODOWEJ NA RZECZ USTABILIZOWANIA SYTUaCJI W AFGanistanie

NA PRZEŁOMIE LISTOPADA I GRUDNIA 2001 R. zorganizowano w Petersbergu w Niemczach konferencję pod egidą Organizacji Narodów Zjednoczonych poświęconą powołaniu władz Afganistanu. 5 grudnia zawarto porozumienie, na mocy którego powołano rząd tymczasowy mający przez kolejne pół roku sprawować nadzór nad sytuacją w Afganistanie, włączając $\mathrm{w}$ to odbudowę państwa oraz zminimalizowanie następstw wojny. Na czele rządu stanął Hamid Karzaj. Celem rządu, poza walką przeciwko talibom, była rekonstrukcja kraju. Miało się to odbywać przy wsparciu ze strony organizacji międzynarodowych oraz państw. Jednakże należy mieć na względzie, że do przejęcia administrowania nad całym państwem przez rząd tymczasowy konieczne było stworzenie systemu, który umożliwiłby współpracę władz stolicy z lokalnymi politykami oraz rozwiązanie problemu konfliktu z pretendentami do władzy ${ }^{10}$.

Utrzymaniu pokoju w Afganistanie miała służyć obecność międzynarodowych sił w Kabulu. Porozumienie w tej sprawie podpisano 4 stycznia $2002 \mathrm{r}^{11}{ }^{1}$. ISAF (ang. International Security Assistance Force) od sierpnia $2003 \mathrm{r}$. pozostaje pod dowództwem Sojuszu ${ }^{12}$. Misja ta doprowadzić ma do przekazania Afgańczykom odpowiedzialności za bezpieczeństwo w państwie. $\mathrm{Z}$ tego też powodu niezwykle ważne jest jej pomyślne zakończenie ${ }^{13}$. Istotne jest ponadto, że pełni ona jedynie rolę wspierającą. Celem jej nie jest zatem przejęcie obowiązków państwa w procesie stabilizowania Afganistanu i jego rekonstrukcji ${ }^{14}$. Do zadań ISAF należały pomoc Tymczasowej Administracji w zapewnie-

8 Zob. M. Kozub, Sojusz Pótnocnoatlantycki w początkach XXI wieku, [w:] Bezpieczeństwo $w$ stosunkach, op. cit., s. 184.

${ }_{9}$ J. Stachura, Bliskowschodnia polityka..., op. cit., s. 38.

${ }^{10}$ P. Jastrzębski, Wojna w..., op. cit., s. 278-281.

${ }^{11}$ Ibidem, s. 282.

12 B. Górka-Winter, Operacja stabilizacyjna NATO $w$ Afganistanie, „Sprawy Międzynarodowe" 2006, nr 3, s. 101.

${ }_{13}$ A. D. Rotfeld, NATO 2020: nowa koncepcja strategiczna, „Sprawy Międzynarodowe" 2010, $\mathrm{nr}$ 4, s. 20, 23.

${ }^{14}$ B. Górka-Winter, Operacja stabilizacyjna..., op. cit., s. 107. 
niu bezpieczeństwa, stworzenie i przeszkolenie sił zbrojnych oraz prowadzenie podstawowej odbudowy infrastrukturalnej ${ }^{15}$.

Przyjęto także zasadę, zgodnie z którą za poszczególne dziedziny sektora bezpieczeństwa odpowiada inne państwo wiodące. Stany Zjednoczone wspierały tworzenie amii narodowej. Wielka Brytania zajmowała się zwalczaniem produkcji narkotyków w Afganistanie ${ }^{16}$. Włochy były odpowiedzialne za wymiar sprawiedliwości, a Japonia za rozbrojenie. Podział ten, dokonany podczas konferencji tokijskiej w styczniu 2002 r., okazał się jednak nieskuteczny i w roku 2005 zrezygnowano $\mathrm{z}$ niego ${ }^{17}$.

W ramach ISAF rozlokowano kilka dowództw oraz 26 zespołów do spraw odbudowy na szczeblu regionalnym ${ }^{18}$. Siły NATO udały się do Afganistanu na podstawie mandatu Rady Bezpieczeństwa ONZ. Obok sił ISAF funkcjonowały wojska Stanów Zjednoczonych walczących przeciwko terroryzmowi ${ }^{19}$. W roku 2014 władze afgańskie mają przejąć całkowitą odpowiedzialność za bezpieczeństwo w kraju. Warto jednak zauważyć, że nawet wówczas niezbędna będzie pomoc sił ISAF, chociażby poprzez przeprowadzanie szkoleń oraz udzielanie wsparcia o charakterze materialnym i sprzętowym ${ }^{20}$.

\section{OdBUDOWA PAŃSTWA AFGAŃSKIEGO}

OdBUDOWE PAŃSTWA MOŻNA PODZIELIĆ NA DWA ETAPY. Na początku konieczne jest przywrócenie spokoju oraz ustanowienie podstawowych elementów życia politycznego, ekonomicznego oraz społecznego. Następnie podejmuje się działania mające doprowadzić do usamodzielnienia politycznego i gospodarczego ${ }^{21}$. Wśród zagrożeń dla bezpieczeństwa wskazać należy: fundamentalizm islamski, terroryzm oraz problem

\footnotetext{
${ }^{15}$ Ibidem, S. 105 .

${ }^{16}$ B. Górka-Winter, Operacja stabilizacyjna..., op. cit., s. 109.

${ }^{17}$ T. Paszewski, Klasycy doktryny wojny antypartyzanckiej a operacja $w$ Afganistanie, „Sprawy Międzynarodowe” 2010, nr 3, s. 38-39.

${ }^{18}$ Zob. M. M. Kosman, EUPOL Afganistan - misja policyjna w cieniu terroryzmu, [w:] Misje cywilne Unii Europejskiej, red. B. Przybylska-Maszner, Poznań 2010, s. 279.

19 R. Kuźniar, NATO $w$ nowym środowisku strategicznym, „Sprawy Międzynarodowe” 2006, nr 3, s. 43.

${ }_{20}$ NATO w roku Lizbony - czas sukcesów warunkowych, „Rocznik Strategiczny 2010. Przegląd sytuacji politycznej, gospodarczej i wojskowej w środowisku międzynarodowym Polski”, Warszawa 2011, s. 89-90.

${ }_{21}^{2}$ R. Fiedler, Od przywództwa do hegemonii. Stany Zjednoczone wobec Bliskowschodniego obszaru niestabilności w latach 1991-2009, Poznań 2010, s. 276.
} 
przemytu narkotyków ${ }^{22}$. Nie bez znaczenia jest także łamanie praw człowieka ${ }^{23}$. Dodatkowymi przyczynami upadku państwowości są ponadto konflikty wewnętrzne i zły system rządów ${ }^{24}$.

W procesie odbudowy państwa afgańskiego konieczne jest zatem uwzględnienie wielu aspektów. Niezbędne jest zreformowanie sektora bezpieczeństwa i jego utrzymanie. Nie bez znaczenia jest fakt lojalności wobec przywódców lokalnych. Kolejny element stanowi panująca bieda. Około 70 procent ludności żyje poniżej granicy ubóstwa. Władze kraju są słabe i zależne od zagranicznych źródeł pomocy. Państwo słynie natomiast $\mathrm{z}$ handlu opium ${ }^{25}$.

Jedną ze słabości Afganistanu stanowi brak rozwiniętej struktury administracyjnej zarówno na poziomie lokalnym, jak i centralnym ${ }^{26}$. Brakuje środków na utrzymanie nowoczesnej administracji. Płace urzędników są bardzo niskie. Przeciętnie jest to 50 dolarów miesięcznie. Dla porównania Afgańczyk pracujący dla organizacji pozarządowej lub międzynarodowej, bądź też w instytucjach Organizacji Narodów Zjednoczonych zarabia około 1 ooo dolarów. Jest to zasadnicza przyczyna odchodzenia pracowników urzędów państwowych na lepiej płatne posady ${ }^{27}$. Problemem Afganistanu jest także korupcja. W 2009 roku sięgała ona poziomu 23 procent $\mathrm{PKB}^{28}$.

Trudności są dostrzegalne także w przypadku armii i policji. Główną wadą armii afgańskiej są niedobory nawet w podstawowym wyposażeniu'29. Do 2006 r. przeszkolono około 30 tysięcy żołnierzy. Szkolenia odbywają się w Centrum Szkolenia w Kabulu ${ }^{30}$. W kwestii współpracy policją najważniejszą rolę odgrywały Niemcy, które od marca 2003 r. działały na rzecz budowy policji afgańskiej. W sierpniu 2002 r. powstała akademia policyjna. Do końca marca 2005 r. ukończyło ją

${ }^{22}$ R. Zięba, Wspólna Polityka Zagraniczna i Bezpieczeństwa Unii Europejskiej, Warszawa 2007, s. 216.

${ }^{23}$ P. Jastrzębski, Wojna w..., op. cit., s. 268.

${ }^{24}$ Zob. S. Koziej, Unia Europejska - Sojusz Pótnocnoatlantycki. Wzajemne relacje $w$ dziedzinie bezpieczeństwa i obronności, [w:] Bezpieczeństwo $w$ stosunkach..., op. cit., s. 140.

${ }^{25}$ B. Górka-Winter, Operacja stabilizacyjna..., op. cit., s. 103-105.

${ }^{26}$ A. Bugajski, B. Winid, Bilans szczytu NATO w Strasburgu i Kehl, „Sprawy Międzynarodowe" 2009, nr 2, s. 47.

${ }_{27}$ M. Garztecki, Ł. Szozda, Świat islamu $i$ nowe zagrożenia, „Sprawy Międzynarodowe" 2007, nr 2, s. 19.

${ }_{28}^{28}$ T. Paszewski, Klasycy doktryny..., op. cit., s. 40.

${ }^{29}$ M. Garztecki, Ł. Szozda, Świat islamu..., op. cit., s. 18.

${ }^{30}$ B. Górka-Winter, Operacja stabilizacyjna..., op. cit., s. 110. 
ponad sześć tysięcy osób ${ }^{31}$. Wśród słabych stron miejscowej policji warto wskazać skorumpowanie, brak wyposażenia, słabe wyszkolenie oraz niskie wynagrodzenie ${ }^{32}$.

W Afganistanie utworzono także Prowincjonalne Zespoły do Spraw Odbudowy (ang. Provicial Reconstruction Team - PRT). Były dowodzone przez ISAF, za ich kierownictwo odpowiadały natomiast kontyngenty narodowe państw ${ }^{33}$. Zajmowały się między innymi wdrażaniem projektów dotyczących odbudowy zniszczonej infrastruktury - szkół, dróg czy ośrodków medycznych. Należy zauważyć, że lepsze warunki życia mieszkańców państwa skutkować będą wzrostem zaufania Afgańczyków do władz centralnych ${ }^{34}$.

Istotnym elementem, o którym nie można zapominać analizując obecną sytuację państwa afgańskiego jest fakt, że stanowi ona w znacznej mierze wynik błędów popełnionych przez Stany Zjednoczone. Wskazać można chociażby, że w roku 2002 środki finansowe przekazane przez USA na odbudowę Afganistanu wynosiły tylko 500 milionów dolarów ${ }^{35}$. Udział Stanów Zjednoczonych w odnowie państwa do 2003 r. koncentrował się praktycznie jedynie na tworzeniu armii. Inne formy nie miały większego znaczenia. Skupienie się na zapewnieniu bezpieczeństwa oraz rozwoju od razu po obaleniu reżimu talibów doprowadziłoby do szybszego osiągnięcia stabilizacji ${ }^{36}$. Brak środków pomocowych, inwestycji oraz niewystarczająca ilość sił międzynarodowych po obaleniu talibów przyczyniły się do powstania wielu problemów. Jednym z nich był brak sprawnej koordynacji pomiędzy działaniami podejmowanymi przez podmioty uczestniczące w procesie stabilizacji kraju. Było to jedną z przyczyn zaburzeń w ich spójności ${ }^{37}$.

Pomoc społeczności międzynarodowej dla Afganistanu w latach 2002-2003 wynosiła jedynie 50 dolarów na jednego mieszkańca w ciągu roku ${ }^{38}$. W latach 2002-2006 Stany Zjednoczone przekazały

${ }^{31}$ M. M. Kosman, EUPOL Afganistan..., op. cit., s. 281.

${ }^{32}$ T. Paszewski, Wojna z terroryzmem - próba bilansu, „Sprawy Międzynarodowe” 2008, nr 2, s. 88.

${ }^{33}$ T. Paszewski, Klasycy doktryny..., op. cit., s. 42.

${ }^{34}$ B. Górka-Winter, Operacja stabilizacyjna..., op. cit., s. 108.

${ }^{35}$ T. Paszewski, Wojna z..., op. cit., s. 86.

${ }^{36}$ Idem, Klasycy doktryny..., op. cit., s. 36-37.

${ }^{37}$ Strategia i taktyka walki asymetrycznej - wnioski z operacji w Afganistanie, „Rocznik Strategiczny 2008, nr 9. Przegląd sytuacji politycznej, gospodarczej i wojskowej w środowisku międzynarodowym Polski”, Warszawa 2009, s. 347-348.

${ }^{8}$ T. Paszewski, Klasycy doktryny..., op. cit., s. 38. 
10,2 miliarda dolarów na pomoc Afganistanowi, z czego 3,9 miliarda przeznaczono na pomoc o charakterze cywilnym ${ }^{39}$. W maju $2002 \mathrm{r}$. powstał fundusz ARTF (ang. Afghanistan Reconstruction Trust Fund) działający pod zarządem ONZ oraz Banku Światowego ${ }^{40}$.

Zorganizowano kilka konferencji dotyczących ustabilizowania sytuacji w Afganistanie. Odbywały się one kolejno w dwuletnich odstępach: w 2002 r. w Berlinie, następnie w Londynie i Paryżu. W 2009 roku miało miejsce spotkanie w Hadze ${ }^{41}$.

W styczniu 2002 r. w Tokio odbyła się konferencja międzynarodowa, która miała na celu wspomaganie odbudowy państwa afgańskiego. Uczestnicy spotkania zadeklarowali przeznaczenie środków finansowych na odbudowę zniszczonego kraju. Przykładowo, Unia Europejska przeznaczyła na ten cel pół miliarda dolarów, podobnie jak Japonia oraz Azjatycki Bank Rozwoju. Stany Zjednoczone, Wielka Brytania oraz Niemcy wygospodarowały ze swych budżetów kwotę niespełna 300 milionów dolarów ${ }^{42}$. Do 2008 r. pomoc finansowa wyniosła 14,5 miliarda dolarów ${ }^{43}$. Sumy te jednak mogą okazać się niewystarczające. Zgodnie z szacunkami Banku Światowego odbudowa kraju po wojnie wyniesie co najmniej 15 miliardów dolarów ${ }^{44}$.

Od 31 stycznia do 1 lutego 2006 r. miała miejsce międzynarodowa konferencja w Londynie. W czasie jej trwania zawarto „Afganistan Compact" - porozumienie przewidujące przekazanie Afganistanowi pomocy od społeczności międzynarodowej oraz wsparcie Afgańczyków w procesie odbudowy zniszczonego państwa ${ }^{45}$. Określono także mechanizm koordynacji działań Afganistanu oraz społeczności międzynarodowej mających na celu utrzymanie pokoju oraz bezpieczeństwa $^{46}$.

28 stycznia 2010 r. odbyła się konferencja w Londynie. Uczestniczyło w niej 400 osób z ponad 70 państw świata i organizacji między-

39 J. Zając, Bliskowschodni kompleks niestabilności $i$ bezpieczeństwa, [w:] Bezpieczeństwa międzynarodowe po zimnej wojnie, red. R. Zięba, Warszawa 2008, s. 387.

${ }^{40}$ M. M. Kosman, EUPOL Afganistan..., op. cit., s. 279.

${ }^{41}$ Ibidem, S. 279.

${ }^{42}$ P. Jastrzębski, Wojna w..., op. cit., s. 282.

${ }^{43}$ T. Paszewski, Klasycy doktryny..., op. cit., s. 38.

${ }^{44}$ Tydzień na świecie. Afganistan, „Polityka” 2002, nr 4, s. 14.

45 R. Zięba, Wspólna Polityka..., op. cit., s. 216.

${ }^{46}$ A. Potyrała, B. Przybylska-Maszner, Leksykon integracji europejskiej $w$ obszarze Wspólnej Polityki Zagranicznej i Bezpieczeństwa i Europejskiej Polityki Bezpieczeństwa i Obrony, Poznań 2009, s. 264. 
narodowych. W jej trakcie debatowano między innymi o przyszłych działaniach w Afganistanie ${ }^{47}$.

\section{Pomoc Ze STRony UniI EuropeJskieJ}

Na terytorium Afganistanu dZiąa nie tylko NATO. Jest ono wspierane przez Unię Europejską w aspekcie cywilnym działań ${ }^{48}$. Na podkreślenie zasługuje fakt, że środki militarne nie są gwarantem ustabilizowania sytuacji w tym państwie. Dlatego też niezwykle istotne jest działanie społeczności międzynarodowej na innych płaszczyznach ${ }^{49}$.

Unia Europejska aktywnie uczestniczy w odbudowie państwa afgańskiego. W tym celu podejmuje zobowiązania o charakterze wieloletnim $^{50}$. W okresie od 2002 do 2006 r. UE przeznaczyła na pomoc rozwojową kwotę około 1,5 miliarda euro, a w kolejnych czterech latach dodatkowo 600 milionów euro, co sprawia, że stała się najważniejszym donatorem w tym państwie. Unia współpracuje także z Afgańską Narodową Strategią Rozwoju. Do roku 2013 planowana jest dalsza pomoc $^{51}$. Ze środków UE finansowana jest między innymi praca pracowników socjalnych, administracyjnych oraz sędziów ${ }^{52}$.

Ważną formą aktywności UE jest misja policyjna EUPOL Afganistan (ang. EU Police Mission in Afganistan), którą utworzono na mocy Wspólnego Działania Rady 2007/369/WPZiB z 30 maja 2007 r ${ }^{53}$. Stanowiła ona odpowiedź Unii na wystosowane do niej w dniu 16 maja 2007 r. przez rząd afgański zaproszenie. Rozpoczęła działalność 30 maja 2007 r. ${ }^{54}$. Jej mandat obowiązuje do 31 maja $2013 \mathrm{r}^{55}$.

Zorganizowanie misji policyjnej na terenie państwa afgańskiego można wiązać z deklaracją Rady zatytułowaną „Podejmując nowe

${ }^{47}$ Bliski i Środkowy Wschód - na rozdrożu, „Rocznik Strategiczny 2010, nr 11. Przegląd sytuacji politycznej, gospodarczej i wojskowej w środowisku międzynarodowym Polski”, Warszawa 2011, s. 249.

48 M. Zaborowski, Jakie stosunki transatlantyckie w XXI wieku?, „Sprawy Międzynarodowe” 2010, $\mathrm{nr}$ 4, s. 37.

49 M. Kozub, Sojusz Pótnocnoatlantycki..., op. cit., s. 191.

${ }^{5}$ A. Potyrała, B. Przybylska-Maszner, Leksykon integracji..., op. cit., s. 264.

${ }^{51}$ Zob. S. Parzymies, Unia Europejska wobec wyzwań i zagrożeń w stosunkach międzynarodowych, [w:] Świat wobec wspótczesnych wyzwań i zagrożeń, red. J. Symonides, Warszawa 2010, s. 610.

${ }^{52}$ B. Górka-Winter, Operacja stabilizacyjna..., op. cit., s. 113.

${ }^{53}$ A. Potyrała, B. Przybylska-Maszner, Leksykon integracji..., op. cit., s. 115.

${ }_{54}$ P. Wawrzyk, Bezpieczeństwo wewnętrzne Unii Europejskiej, Warszawa 2009, S. 125 .

55 EUPOL Afganistan http://www.consilium.europa.eu/eeas/security-defence/euoperations/eupol-afghanistan.aspx?lang=en, 19.11.2011 r. 
partnerstwo UE - Afganistan” z 16 listopada 2005 r. Unia Europejska oraz rząd Islamskiego Państwa Afganistanu zadeklarowały w niej chęć dążenia do bezpiecznego, stabilnego i demokratycznego państwa afgańskiego ${ }^{56}$.

Misja EUPOL Afganistan współuczestniczy w procesie ustanowienia efektywnej policji afgańskiej. Wśród jej zadań znajdują się doradztwo, monitorowanie i nadzór funkcjonowania Ministerstwa Spraw Wewnętrznych w zakresie wymiaru sprawiedliwości oraz policji. Przeprowadzane są także szkolenia władz lokalnych i policjantów ${ }^{57}$. Zadaniem misji jest jednocześnie praca nad stworzeniem strategii poświęconej reformie policji i wdrożeniu jej w życie ${ }^{58}$. Misja ma przyczynić się do podniesienia poziomu zaufania obywateli, wspiera spójne wdrażanie strategii przez władze Afganistanu ${ }^{59}$. Personel misji uczestniczy w procesie implementacji strategii antykorupcyjnej oraz bierze udział $\mathrm{w}$ tworzeniu skutecznego systemu postępowania w sprawach o charakterze kryminalnym ${ }^{60}$. Zajmują się prowadzeniem śledztw w sprawach kryminalnych, działalnością rozpoznawczą, rozbudową współpracy pomiędzy policją, a prokuraturą. Uczestniczą w promowaniu praw człowieka. Kolejną płaszczyzną działalności misji jest organizacja seminariów i konferencji. Misja przeszkoliła policję afgańską w celu bezpiecznego przeprowadzenia wyborów prowincjonalnych i prezydenckich. Wybory te odbyły się 20 sierpnia 2009 r. w Afganistanie ${ }^{61}$.

30 listopada 2007 r. utworzono Komitet Uczestników Misji. W jego ramach omawiano sprawy dotyczące bieżącego kierowania EUPOL Afganistan. Pełni także funkcję opiniodawczą w stosunku do Komitetu Politycznego i Bezpieczeństwa ${ }^{62}$. W EUPOL Afganistan uczestniczą państwa należące do Unii Europejskiej oraz Chorwacja, Nowa Zelandia, Kanada i Norwegia ${ }^{63}$. Operację realizowano na całym terytorium Afganistanu. Budżet misji określono na 43,6 miliona euro ${ }^{64}$.

${ }^{56}$ P. Wawrzyk, Bezpieczeństwo wewnętrzne..., op. cit., s. 124.

${ }^{57}$ A. Potyrała, B. Przybylska-Maszner, Leksykon integracji..., op. cit., s. 115 .

${ }^{8}$ J. Barcik, Europejska Polityka Bezpieczeństwa i Obrony. Aspekty prawne i polityczne, Bydgoszcz-Katowice 2008, s. 320.

${ }^{59}$ P. Wawrzyk, Bezpieczeństwo wewnętrzne..., op. cit., s. 125.

${ }^{60}$ EUPOL Afghanistan (EU Police Mission in Afganistan) http://www.msz.gov.pl/ EUPOL,Afghanistan,(EU,Police,Mission,in,Afganistan),29550.html, 19.11.2011 r.

${ }^{61}$ M. M. Kosman, EUPOL Afhanistan..., op. cit., s. 283, 286.

${ }^{62}$ Ibidem, s. 284.

${ }^{63}$ EUPOL Afghanistan (EU Police Mission in Afganistan) http://www.msz.gov.pl/ EUPOL,Afghanistan,(EU,Police,Mission,in,Afganistan),29550.html, 19.11.2011 r.

${ }^{64}$ A. Potyrała, B. Przybylska-Maszner, Leksykon integracji..., op. cit., s. 115. 
Personel misji funkcjonuje na różnych szczeblach, działa zarówno na poziomie regionalnym i w prowincjach oraz w Ministerstwie Spraw Wewnętrznych. Funkcjonuje także w Kabulu w sekretariacie rady ds. koordynacji sił policyjnych ${ }^{65}$. Misja przyczyni się do budowy prawidłowych metod działania w państwie ${ }^{66}$. Oddelegowani przedstawiciele państw członkowskich uczestniczą także w budowie trwałych wzorców rozwiązań stosowanych przez policję afgańską ${ }^{67}$. Unia Europejska pełni kluczową rolę w procesie stabilizacji oraz odbudowy państwa afgańskiego ${ }^{68}$.

10 grudnia $2001 \mathrm{r}$. Unia Europejska ustanowiła specjalnego przedstawiciela dla Afganistanu. Stanowisko to objął wówczas Niemiec Klaus Peter Klaiber ${ }^{69}$. Obecnie jest nim litewski dyplomata Vygaudasa Ušackas. Jego mandat przedłużono do 30 czerwca $2012 \mathrm{r}^{70}$. Zadanie specjalnego przedstawiciela polega na wspieraniu znaczenia ONZ na terenie Afganistanu. Współpracuje także ze specjalnym przedstawicielem Sekretarza Generalnego $\mathrm{ONZ}^{71}$. Popiera realizację porozumienia „Afghanistan Compact” oraz deklaracji zawartej pomiędzy UE, a Afganistanem. Unia udziela także pomocy finansowej. W okresie od 2003 do 2006 r. wynosiła ona 3,7 miliarda dolarów, a w okresie od 2007 do 2010 r. - 610 milionów dolarów. Państwa członkowskie wspierają policję afgańską za pośrednictwem inicjatywy LOFTA (ang. Law and Order Trust Fund for Afganistan) ${ }^{72}$.

Na początku roku 2002 utworzono w Afganistanie Biuro Komisji Europejskiej do spraw Pomocy Humanitarnej ${ }^{73}$. Celem ECHO jest przekazywanie otrzymywanej pomocy humanitarnej. W lutym tego samego roku otwarto w Kabulu przedstawicielstwo Komisji Europejskiej, którego zadaniem jest wspieranie programów pomocowych ${ }^{74}$.

${ }^{65}$ J. Barcik, Europejska Polityka..., op. cit., s. 320.

${ }^{66}$ M.M. Kosman, EUPOL Afganistan..., op. cit., s. 288.

${ }^{67}$ EUPOL Afghanistan (EU Police Mission in Afganistan) http://www.consilium. europa.eu/eeas/security-defence/eu-operations/eupol-afghanistan.aspx?lang=en, 19.11.2011 r.

${ }^{68}$ EU Engagement in Afganistan. http://www.consilium.europa.eu/uedocs/cmsUpload/100218\%20EU\%2oengagement\%20Afghanistan-version5_EN.pdf, 19.11.2011 r.

${ }^{69}$ R. Zięba, Wspólna Polityka..., op. cit., s. 216.

${ }^{70}$ Komunikat Prasowy, 3106. Posiedzenie Rady. Sprawy zagraniczne, Bruksela, 18 lipca 2011 r., Presse 246 PR CO 48, http://www.consilium.europa.eu/uedocs/cms_ data/docs/pressdata/PL/foraff/123975.pdf , 12.11.2011 r.

${ }^{71}$ R. Zięba, Wspólna Polityka..., op. cit., s. 216.

${ }^{72}$ A. Potyrała, B. Przybylska-Maszner, Leksykon integracji..., op. cit., s. 264.

${ }_{73}$ M. M. Kosman, EUPOL Afganistan..., op. cit., s. 280.

${ }^{74}$ R. Zięba, Wspólna Polityka..., op. cit., s. 216. 
16 listopada 2005 r. Unia Europejska i Afganistan podpisały deklarację dotyczącą partnerstwa. W jego ramach przewidziano podejmowanie działań zmierzających do zreformowania politycznego i gospodarczego, zmian w zakresie sektora bezpieczeństwa oraz wymiaru sprawiedliwości, rozwoju społecznego oraz zwalczenia handlu narkotykami ${ }^{75}$. Podkreślono $\mathrm{w}$ niej jednocześnie, że Afganistan powinien stać się aktywnym członkiem społeczności międzynarodowej. Zobowiązano się również do działania na rzecz budowy przyszłości pozbawionej terroryzmu ${ }^{76}$.

Polska także aktywnie uczestniczy w procesie odbudowy zniszczonego państwa afgańskiego. Polska Akcja Humanitarna zrealizowała wiele projektów, m.in. odbudowano i w części wyposażono Średnią Szkołę Muzyczno-Plastyczną, Średnią Zawodową Szkołę Rolniczą w stolicy, wybudowano szkołę w Koko Kheil i zbudowano osiem studni w prowincji Kapisa ${ }^{77}$. Pomocy szkołom i uniwersytetom afgańskim udziela również stowarzyszenie „Szkoły dla Pokoju” poprzez dostarczanie podręczników, materiałów biurowych i komputerów ${ }^{78}$. Pomocy w zakresie poprawy ochrony zdrowia udziela Polska Misja Medyczna ${ }^{79}$. W 2011 r. Ministerstwo Spraw Zagranicznych przeznaczyło kwotę 7,5 miliona dolarów. Do tej pory zrealizowano między innymi następujące projekty: zbudowano w mieście Ghazni mechaniczną oczyszczalnię ścieków, składowiska odpadów oraz most na rzece Saye Do $\mathrm{Ab}^{80}$.

\section{PROBLEM PRODUKCJI I PRZEMYTU NARKOTYKÓW}

Narkobiznes stanowi palący problem Afganistanu. Państwo to mieści się w gronie światowych liderów pod względem produkcji narkotyków. Około 90 procent opium trafiającego na rynek europejski pochodzi właśnie z Afganistanu ${ }^{81}$. Zgodnie z danymi Biura Kontroli Narkotyków

75 Ibidem, s. 216.

${ }^{76}$ P. Wawrzyk, Bezpieczeństwo wewnętrzne..., op. cit., s. 124.

77 Polska Akcja Humanitarna http://www.afghanembassy.com.pl/cms/pl/polskapomoc-dla-afganistanu/polska-akcja-humanitarna, 15.11.2011 r.

${ }^{78}$ Stowarzyszenie Szkoły dla Pokoju http://www.afghanembassy.com.pl/cms/pl/ polska-pomoc-dla-afganistanu/stowarzyszenie-szkoly-dla-pokoju, 15.11.2011 r.

79 Polska Misja Medyczna http://www.afghanembassy.com.pl/cms/pl/polska-pomoc-dla-afganistanu/polska-misja-medyczna, 15.11.2011 r.

8o Polska pomoc dla mieszkańców prowincji Ghazni $w 2011$ r. http://www.isaf. wp.mil.pl/pl/123.html, 15.11.2011 r.

${ }^{81}$ Zob. A. Jaskulski, The European Security Strategy and National Security Strategy of United States of America: Common Aims Or Two Different Views on International Security, [w:] Beyond Borders. External Relations of the European Union, ed. J. Jańczak, Poznań 2008, s. 104. 
ONZ w 1999 roku wyprodukowano tam 4,5 tysiąca ton opium, które może posłużyć do produkcji 450 ton czystej heroiny ${ }^{82}$. Natomiast w roku 2007 jego produkcja wyniosła 8 tysięcy ton ${ }^{83}$. Dwa lata później powierzchnia upraw maku wynosiła ponad 120 tysięcy hektarów ${ }^{84}$. Eksport opium stanowi aż 34 procent dochodu narodowego brutto Afganistanu ${ }^{85}$.

Uprawy opium prowadzą do wzrostu korupcji, destabilizacji w sąsiadujących z Afganistanem państwach. Zagrażają zdrowiu i życiu obywateli państw, do których opium jest przemycane. Prawdopodobnie są też źródłem dochodu dla fundamentalistów ${ }^{86}$.

W odpowiedzi na prośbę władz afgańskich w październiku 2008 r. zadecydowano o rozszerzeniu działalności ISAF o walkę z przemytem narkotyków ${ }^{87}$. W ramach ISAF dostarczana jest pomoc techniczna policji narkotykowej (ang. Counter Narcotics Police of Afghanistan - CNPA) i NUI (ang. National Interdiction Unit). Udzielane jest także wsparcie przy transporcie zarekwirowanych narkotyków oraz ich niszczeniu $^{88}$. Także Rosja wspiera zwalczanie procederu przemytu narkotyków z obszaru tego państwa ${ }^{89}$.

Mimo zmniejszającej się liczby nielegalnych upraw maku, zbiory opium są nadal ogromne. W 2009 r. z 20 na 34 wzrosłą liczba prowincji, w których nie jest ono uprawiane ${ }^{90}$. Wśród przyczyn będących podłożem tego procederu znajdują się ubóstwo, wysoka cena opium oraz brak wsparcia ze strony rządu ${ }^{91}$. Maria E. Sokalska podkreśla, że niezbędne $\mathrm{w}$ walce $\mathrm{z}$ narkobiznesem są interwencje o charakterze społeczno-ekonomicznym: stworzenie rolnikom możliwości godnego życia bez konieczności odwoływania się do upraw opium, promowanie wartości demokratycznych i strategii zapobiegania występowaniu tego zjawiska ${ }^{92}$.

\footnotetext{
${ }^{82}$ P. Jastrzębski, Wojna w..., op. cit., s. 267.

${ }^{8}$ Zob. M. E. Sokalska, Strategia przeciwdziatania narkomanii - wyzwania wobec nowych zagrożeń, [w:] Świat wobec współczesnych, op. cit., s. 551.

${ }^{84}$ T. Paszewski, Klasycy doktryny..., op. cit., s. 40.

${ }^{85}$ M. E. Sokalska, Strategia przeciwdziałania..., op. cit., s. 552.

${ }^{86}$ J. Zając, Bliskowschodni kompleks..., op. cit., s. 368-369.

${ }^{87}$ M. E. Sokalska, Strategia przeciwdziałania..., op. cit., s. 552.

${ }^{88}$ B. Górka-Winter, Operacja stabilizacyjna..., op. cit., s. 110-111.

${ }^{89}$ A. D. Rotfeld, NATO 202O..., op. cit., s. 18.

${ }_{90}$ M. E. Sokalska, Strategia przeciwdziałania..., op. cit., s. 551.

${ }^{91}$ J. Zając, Bliskowschodni kompleks..., op. cit., s. 368.

${ }^{92}$ Cyt. za: M. E. Sokalska, Strategia przeciwdziałania..., op. cit., s. 565.
} 
Na lata 2007-2013 Komisja Europejska wydała dokument Country Strategy Paper. Wspomniano w nim między innymi o działaniach wspierających walkę z produkcją i sprzedażą narkotyków oraz wzmocnieniu struktur na poziomie lokalnym ${ }^{93}$.

Modernizacja jest dla Afganistanu wyzwaniem trudnym do sprostania. Wynika to między innymi z ułomności, niedorozwoju oraz braku ładu prawnego w tym kraju ${ }^{94}$. Niestety wszystkie działania zmierzające do ustabilizowania Afganistanu przynoszą niewielkie rezultaty. Wśród przyczyn takiego stanu rzeczy należy wskazać korupcję, nieodpowiednie wydatkowanie pieniędzy. Elementy te wpływają na wzrost niechęci mieszkańców Afganistanu do podejmowanych działań ${ }^{95}$. Nie bez znaczenia jest także ogromne ubóstwo i problemy mieszkańców. Zgodnie z Raportem o Rozwoju Społecznym za rok 2011 Afganistan znajduje się na 172 miejscu, co jednoznacznie potwierdza trudną sytuację kraju ${ }^{96}$.

Coraz większe problemy w utrzymaniu bezpieczeństwa zdają się potwierdzać, że podejmowane do tej pory wysiłki nie są skuteczne. Nie można jednak nie zauważać osiągniętych sukcesów. Nie zmienia to jednak faktu, że mimo upływu lat w Afganistanie nadal nie funkcjonują sprawnie organy wymiaru sprawiedliwości oraz policja. Dostrzegalny postęp w odbudowie infrastrukturalnej jest nieznaczny. Zasadniczym problemem pozostaje wciąż produkcja narkotyków ${ }^{97}$.

Należy jednak zauważyć, że w państwie tym tkwi niewykorzystany potencjał. Kraj jest bogaty w zasoby, które mogą zostać wykorzystane przez przemysły wydobywczy i przetwórczy. Brak jest także ośrodków kształcących. Mimo istnienia uniwersytetu w stolicy działa on jedynie częściowo. Z kolei pomoc finansowa od społeczności międzynarodowej jest przekazywana wyłącznie na szkolnictwo na poziomie podstawowym ${ }^{98}$.

${ }_{93}$ M. M. Kosman, EUPOL Afganistan..., op. cit., s. 280-281.

${ }^{94}$ M. Garztecki, Ł. Szozda, Świat islamu..., op. cit., s. 15.

95 J. Zając, Bliskowschodni kompleks..., op. cit., s. 389.

${ }_{96}$ Human Development Index (HDI) - 2011 Rankings, http://hdr.undp.org/en/ statistics/, 15.11.2011 r.

${ }^{97}$ Strategia i taktyka..., op. cit., s. 353.

${ }_{98}^{8}$ M. Garztecki, Ł. Szozda, Świat islamu..., op. cit., s. 20-21. 


\section{SUMMARY}

Afghanistan IS ONE OF THE MOST UNSTABLE COUNTRIES IN THE WORLD. The process of reconstruction began in 2001 when Taliban regime was defeated. It is difficult to stabilize situation in Afghanistan. Stabilization requires the help from an international community, especially the European Union, the ISAF and the United States of America. The support is mostly financial and material. However, there are many problems such as production and smuggling of drugs. Another problem is also Afghans' huge poverty. These factors influence the completion of tasks negatively.

NotA O AUTORCE

Anna Wesołowska-Maciejewska - [a.wesolowska-maciejewska@ wp.pl] - absolwentka stosunków międzynarodowych, specjalności: dyplomacja i stosunki konsularne, współpraca europejska, gospodarka światowa i biznes międzynarodowy. Obecnie doktorantka na Wydziale Nauk Politycznych i Dziennikarstwa Uniwersytetu im. Adama Mickiewicza w Poznaniu. Jej zainteresowania koncentrują się na politycznej i gospodarczej roli Unii Europejskiej na arenie międzynarodowej. 